\section{LEXICON}

https://jurnal.ugm.ac.id/lexicon

\title{
New Woman as Seen in Bram Stoker's Dracula
}

\author{
Rheavanya Winandhini, Rahmawan Jatmiko* \\ English Department, Universitas Gadjah Mada, Indonesia \\ *Corresponding Author: rahmawan.jatmiko@ugm.ac.id
}

\begin{abstract}
This paper discusses the influence of feminism in the classic Victorian novel Dracula by Bram Stoker. The New Woman is a feminist ideal that appeared in the 19th century, more specifically amidst the rise of the first wave of feminism. The method of research used in this study covers close reading of the source material and analyzing the characters of the novel through the perspective of the New Woman ideals. The female characters in Bram Stoker's Dracula portrayed the New Woman characteristic to some degree. Women's independence, intellect, hyperfemininity, and hypersexuality, are some of the aspects of the movement that go against the norm and values of women in Victorian Britain, such as Mina's "man's brain" and Lucy's hyperfemininity, while the Brides of Dracula provide contrast as the oppressed women with their submissive and compliant attitude towards him. Without erasing their representation of these New Woman ideals, Mina and Lucy also portrayed the complexity and dimensionality of being a woman in the Victorian era; their beauty and appeal were praised while their more "unwomanly" aspects present some threats towards men.
\end{abstract}

Keywords: first wave feminism, New Woman, Victorian Britain, Bram Stoker, Dracula.

\section{INTRODUCTION}

Bram Stoker's Dracula was published in 1897 and set in the Victorian era; and at that time, people still lived in a patriarchal society, and they had a strong male dominance culture. A British Library article, Gender Roles in the 19th Century, written by Kathryn Hughes in 2014, stated that "Women were considered physically weaker yet morally superior to men, which meant that they were best suited to the domestic sphere." It means that women were expected to do household chores and compensate for the moral taint of the public domain, and women's influence in the household was used as an argument against giving them the right to vote. Marriage and motherhood were seen as an obligation rather than a choice. According to Abrams (2001), women who chose not to become a mother was considered liable, or even a failure, and her spiritual fulfillment was determined by her motherhood. Women had financial and sexual disadvantages, experiencing marriages and social status inequalities, and significant differences in terms of rights and privileges. Education was also one of the things that women cannot pursue in that era. Unlike men, women were not offered the opportunity to study further, and it was believed that studying was against women's nature and they were only seen as an ornament. As observed by Kent (1990), "women were so exclusively identified by their sexual functions that nineteenth-century society came to regard them as 'the Sex'”. (p. 32) 
The reason for choosing this work is that in the late nineteenth century, a feminist ideal called the New Woman emerged and influenced feminism in society in that era. The main idea of New Woman is to push the limit put on women by the maledominated society. Many literary works published in the Victorian era portray the New Woman ideal, including Dracula. Other examples are Jude the Obscure by Thomas Hardy (1896), Vanity Fair by William Makepeace Thackeray (1874), The Bleak House by Charles Dickens (1852), and some by Sarah Grand herself, the person who coined the term New Woman. Some of her fictional works are Ideala (1888), The Heavenly Twins (1893), and The Beth Book (1897). Even though Dracula was not the only fiction novel containing female characters that portray this ideal, it was a unique piece of literary work in a sense that it was one of the firsts that took place in a fantasy world with its own lore and mythology.

\section{LITERATURE REVIEW}

So far, there have been a few studies on Bram Stoker's work done by Kathryn Boyd from Trinity University titled Making Sense of Mina: Stoker's Vampirization of the Victorian Woman in Dracula in 2014 and Nancy F. Rosenberg from Marymount University titled Desire and Loathing in Bram Stoker's Dracula. They emphasize the sexuality of the women in Dracula and how Stoker characterized them as women who were not afraid to show their sexual appeal, in contrast to how women were supposed to behave in the Victorian era.

Another study was done by Carol A. Senf from Georgia Tech titled Rethinking the New Woman in Stoker's Fiction, although the literary work she used is not Dracula, but another Bram Stoker's work titled Lady Athlyne. Senf also emphasizes the New Woman of this literary work, and it can be used as a reflection on other Bram Stoker's literary works and the New Woman.

There is also a study done by Lora Cvetanova from Université Toulousell, Le Mirail, in 2014, titled Bram Stoker's Dracula, Feminist Theory and Sexuality, which discusses how the novel is built on a patriarchal ideology and only see a woman as the supporting role of the men characters. This study is different from the present paper because it uses a different perspective on the women characters.

Another paper entitled 'The Emancipation of Mina? The Portrayal of Mina in Stoker's Dracula and Coppola's Bram Stoker's Dracula', written by Mewald (2008) from University of Vienna, emphasizes only one character and how she portrays feminism in the novel.

Though the present paper focuses on the representation of the New Woman in Bram Stoker's novel Dracula, which is different from the previous papers, all of them are still related to the feminist idea that appears in the novel and the women characters. They provide more insight and contrast on Bram Stoker's works and his concept of feminism.

\section{THEORETICAL FRAMEWORK}

The idea and spirit of feminism were slowly appearing in this era, with the New Woman movement starting to takeoff. As mentioned previously, the term 'New Woman' itself was coined for the first time by Sarah Grand in her seven pages long essay titled The New Aspect of the Woman Question in 1894, which was published in The North American Review (Vol. 158, No. 448, p. 270-276), a literature magazine by University of Northern Iowa. Grand voices her criticism and frustration about men's, more specifically the Bawling Brothers', degrading attitude towards women, claiming, "If women don't want to be men, what do they want?" as Grand herself quoted in the first paragraph of her essay. The essay continues with Grand explaining that women are starting to realize that they deserved better than what society had conditioned them to be, and they are beginning to look for more, even when they are still trying to figure things out. This, however, upsets the patriarchy, and men started their own protests. Without exactly knowing or understanding the problems, they offered their unsolicited opinions and advice. Grand also satirically states that men are not the only ones to blame, as women have been so compliant, allowing, enduring, and accepting the way society treated and looked upon them. She criticized the patriarchal society for limiting women's education and freedom, 
yet they were judged for it (Grand, 1894, pp. 271272).

Grand finishes her essay by saying that it is both women's and men's job to make society a better place and set the human household in order. If women and men work together toward a more understanding environment, then all of them will benefit from it.

While the New Woman itself does not have specific rules or guidelines, it definitely has its characteristics and ideals to help analyzed and understand more the character's thoughts and choice of actions.

\section{METHODS}

Data collection consists of the primary data, or the object material of this research is the literary work itself, Dracula and the feminist and the New Woman idea is the focus of the arguments in the research. Close reading the materials is an essential part of the study to better understand the intrinsic elements such as plot and theme. This could be developed into research questions and objectives for analyzing purposes. Library and online research are also necessary to collect data such as theories on feminism in analyzing Dracula to support and give information about feminist ideology in the Victorian era, especially about the New Woman and how it can be found in literary work. Related writings in journals are also needed to help this research.

Data analysis is conducted with the present writer reads the primary sources, the novel, through close reading to get a deeper understanding of the women characters in the story. Character analysis is needed to give evidence of the roles of the female characters. Therefore, it can be analyzed further using the perspective of the New Woman ideals. Secondary sources and guides are used to help the researcher to understand more about feminist criticism that is applied in the analysis and to provide the historical background of gothic fictions such as Dracula that can be used as a source to compare the history of the Victorian era and how it is implied in the novel.

\section{RESULTS AND DISCUSSION}

\section{Victorian Britain in Bram Stoker's Dracula}

The Victorian era's standards towards women and the beginning of the feminist movements played a part in the story. The idea that women were portrayed as something independent or resourceful is a relatively unfamiliar concept for men. As the women's movement, such as the Suffrage, started taking off, there are specific characteristics in Dracula's depiction of women that could be observed and perceived as the representation of Victorian's New Woman. The hyperfemininity and hypersensitivity of women, their independence, desire to pursue a career outside the house, and women's sexual tendencies and freedom are several aspects of the New Woman ideal that could be examined in the book's female characters. Podonsky's article pointed out that this particular passage portrayed men's complicated feelings towards women's forwardness, stating that "temptation made the "unnatural" occurrence of female sexual advances desirable (as it was the "forbidden fruit"), yet from a God-believing gentleman's standpoint, it was pure evil and almost animalistic." It implies that women's appeal and seductiveness could only be directed towards men and that men's sexual attraction was not his responsibility, as it was still considered the women's fault for "deliberately tempting a man to "take the forbidden fruit" himself; another reference to evil's association with a woman's sexuality" and for "defying the set social expectations for proper ladies, as the men could not easily control what was natural to them." (Podonsky, 2010, p. 1)

\section{The Brides of Dracula}

The first female characters that the book introduced were the three seductive vampire "sisters". They were the brides of Count Dracula and they appeared rather early in the story when Jonathan Harker, a lawyer and the main male protagonist of the story, was trapped in the Transylvania castle. He was seduced by the vampires as he started to fall asleep in one of the rooms, which he was warned against by the Count, and almost fell victim to their blood thirst. 
Fortunately for Jonathan, Dracula still needed him at the time so he was saved; he said to his brides, "Well, now I promise you that when I am done with him, you shall kiss him at your will." (Stoker, 1993, p. 34). Keeping his promise, Jonathan heard the Count said to the brides one day before his departure that they need to be patient and that they can have him tomorrow night, seeing as he was finally done with him. Jonathan then decided to escape from the castle to avoid the gruesome fate and started making his own way back to England.

The brides were described as beautiful, enchanting women with ruby-red voluptuous lips and white teeth. And though they were known as the Brides of Dracula or the weird sisters, it was never really explained who exactly they were. They resided in Dracula's Castle and roamed around to look for food (or a victim, to be more precise) that Dracula had left for them. In contrast to how other male characters spoke to and treated Mina or Lucy, Dracula was very savage and crude to his brides. For instance, Jonathan always regarded Mina delicately and with love, even when Mina was under Dracula's spell and was just forced to drink his blood, Jonathan still showed compassion to Mina when she insisted that she was "unclean" and that she should not touch or kiss his husband anymore.

"Nonsense, Mina. It is a shame to me to hear such a word. I would not hear it of you. And I shall not hear it from you. May God judge me by my deserts, and punish me with more bitter suffering than even this hour, if by any act or will of mine anything ever come between us!" (Stoker, 1993, p. 236)

Meanwhile, the Count continually displayed his dominance over them by means of physical superiority as a reference to the patriarchal traditions' bias and the "common belief that women were the inferior sex as they were physically weaker than their male counterparts." (Podonsky, 2010, p. 2) This shows when he caught the brides as they were about to strike Jonathan.

"With a fierce sweep of his arm, he hurled the woman from him, and then motioned to the others as though he were beating them back; it was the very same imperious gesture that I had seen used to the wolves." (Stoker, 1993, p. 34)
Podonsky also noted that the Count demonstrated intellectual superiority as well as physical; "he has the women 'trained' in such a manner that the narrator of the passage compares it to the domestication of animals (the wolves)." The vampire "sisters" seem to have a dependent relationship with Dracula. They do as he told them to and wait for him to bring them food (or victim), "perfectly imitating the expectations of a forcefully male-dominated society, and recognizing the fact that women have a scarce quantity of rights available to them as opposed to the liberated Caucasian male." (Podonsky, 2010, p. 2)

"How dare you touch him? Any of you! How dare you cast eyes upon him when I had forbidden it? Back, I tell you all! Beware how you meddle with him, or you shall have to deal with me!" (Stoker, 1993, p. 34)

The "sisters" provide a comparison to Mina and Lucy, who had their freedom and independence. Their submissiveness and dependence on Dracula established that they were portrayed as the oppressed and controlled women in the novel. Even when Dracula treated them like animals and very constrictive of them, they never retaliated. They were not allowed to leave the castle and only feed on victims that he brought to them, in contrast to Lucy, who, even after became a member of the undead, still hunt her own victims.

\section{Mina Harker}

Mina is portrayed in the book as the ideal Victorian woman, and it was depicted through her feelings, emotions, and convictions. She was beautiful, sweet, sensitive, kind, very loving, and gentle, as proven by her devotion to her loved ones and how much she cares for them when they are ill or in trouble. Though she was described as the stereotypical Victorian woman and was submissive to his fiancée, she showed another side of her that could be identified as the New Woman aspect in her personality, as she was quite independent and intelligent. In one of her letters to Lucy, she mentioned her busy job as an assistant schoolmistress: "Forgive my long delay in writing, but I have been simply overwhelmed with work. The life of an assistant schoolmistress is sometimes trying." (Stoker, 1993, p. 46) As previously discussed, 
the Women's Movement in the $19^{\text {th }}$ century played a part in giving young women the encouragement to start working before marriage.

Mina's intelligence is shown in her ability and interest in modern technologies. She was very experienced in shorthand, a method of writing that uses abbreviated symbols to write short and fast messages to Jonathan when he was in Transylvania. She was rather fond of her typewriter, as she had written everything with it and not to mention her knowledge of using the phonograph. She was a determined person and quite independent when need be. However, seeing that Mina still holds her traditional Victorian values, she acknowledged that her ambition to work harder is because she wanted to keep up with Jonathan and help him after getting married.

"I have been working very hard lately, because I want to keep up with Jonathan's studies, and I have been practicing shorthand very assiduously. When we are married I shall be able to be useful to Jonathan, and if I can stenograph well enough I can take down what he wants to say in this way and write it out for him on the typewriter, at which also I am practicing very hard." (Stoker 1897: 46)

To further analyze the complexity of Mina's character, Charles E. Prescott and Grace A. Giorgio stated in their 2005 paper Vampiric Affinities: Mina Harker and the Paradox of Femininity in Bram Stoker's Dracula, that the ultimate New Woman moment for Mina is when the protagonist group was trying to hunt and kill Dracula. She contributed by taking the role of the lady journalist that she has yearned to be. She assembled and distributed the journals, letters, and all the writings they had to the group to look for clues and leads. Both her womanly attributes and intellect did not get overlooked as she caught Van Helsing's attention and he constantly "praise of her man's brain and woman's heart", so much that even her own fiancée took notice of this, "I would listen to him go on praising Mina for a day, so I simply nodded and stood silent." (Stoker, 1993, p. 156) Van Helsing first praised her for being the perfect example of a Victorian woman.

"She is one of God's women, fashioned by His own hand to show us men and other women that there is a heaven where we can enter, and that its light can be here on earth. So true, so sweet, so noble, so little an egoist, and that, let me tell you, is much in this age, so sceptical and selfish." (Stoker, 1993, p. 156)

Then, in later parts of the book, Van Helsing started to observe and applaud her for her ambition and dedication:

"Ah, that wonderful Madam Mina! She has man's brain, a brain that a man should have were he much gifted, and a woman's heart. The good God fashioned her for a purpose, believe me, when He made that so good combination. Friend John, up to now fortune has made that woman of help to us, after tonight she must not have to do with this so terrible affair. It is not good that she run a risk so great." (Stoker, 1993, p. 195)

Still, even with his acknowledgement and admiration of Mina's abilities, Van Helsing insisted that she should not participate in the action of hunting and killing the vampires. He still believes that women do not belong in dangerous circumstances and that she would not be able to protect herself and be too scared to face the threat. This proves that the men do not see and think of Mina as their equal. In his words:

"We men are determined, nay, are we not pledged, to destroy this monster? But it is no part for a woman. Even if she be not harmed, her heart may fail her in so much and so many horrors and hereafter she may suffer, both in waking, from her nerves, and in sleep, from her dreams. And, besides, she is young woman and not so long married, there may be other things to think of some time, if not now. You tell me she has wrote all, then she must consult with us, but tomorrow she say goodbye to this work, and we go alone." (Stoker, 1993, p. 195)

Mina was quite aware of this as well. After the death of Lucy, she met two of the three gentlemen who proposed to Lucy and made a comment regarding their obliviousness of her knowledge, "Poor fellows, neither of them is aware that I know all about the proposals they made to Lucy. They did not quite know what to say or do, as they were ignorant of the amount of my knowledge." (190) Mina's complexity of a female character also further demonstrated in her motherly nature. She was 
portrayed as very nurturing, tending and taking care of Lucy when she was ill and suffering from severe anemia and chronic blood loss, as well as sleepwalking as she fell victim to Dracula and slowly turning into the undead herself. As previously established, the ideal Victorian woman is one who embraces her motherhood role, but it also can be argued that Mina's deep perception of feelings and sensitivity could be translated as the New Woman's aspect of hyperfemininity. "She was a creature whose proper feminine affectivity, 'the dearer, tenderer emotions of the true woman', had become excessive and degenerate and had thus entered the domain of the improper feminine'”. (Pykett, 1992, p. 140) Mina showed her motherly side throughout the book; for example, is the fact that she became Jonathan's rock while he recovered and stabilized from his encounter with the Count. Another one of those moments came when she first met one of Lucy's fiancée, Arthur Holmwood (Lord Godalming after his late father). She let him rest on her shoulder while he wept in grievance even though they never met before, and she offered him comfort and to be his "sister" in honor of her sisterhood with Lucy.

"We women have something of the mother in us that makes us rise above smaller matters when the mother spirit is invoked. I felt this big sorrowing man's head resting on me, as though it were that of a baby that some day may lie on my bosom, and I stroked his hair as though he were my own child. I never thought at the time how strange it all was." (Stoker, 1993, p. 191)

In the book, Mina herself was also aware of the New Woman movement. She mentioned it in her journal while detailing the day that she had with Lucy. However, it did come across as though she still had her belief that men are superior and more lenient than progressive women. She commented about what the New Woman would think about her and Lucy's "unwomanly" appetites and claimed that men would not mind it instead.

"I believe we should have shocked the "New Woman' with our appetites. Men are more tolerant, bless them! Then we walked home with some, or rather many, stoppages to rest, and with our hearts full of a constant dread of wild bulls." (Stoker, 1993, p. 75)
In contrast, she also expressed her respect and appreciation to the New Woman by voicing the idea that someday in the future, women would start proposing to men instead of being proposed. This shows that Mina is not a one-dimensional character and cannot be defined by only her Victorian woman ideal or her New Woman element. She is both.

'Some of the 'New Women' writers will some day start an idea that men and women should be allowed to see each other asleep before proposing or accepting. But I suppose the 'New Woman' won't condescend in future to accept. She will do the proposing herself. And a nice job she will make of it too!" (Stoker, 1993, p. 75)

\section{Lucy Westenra}

Lucy Westenra is the best friend of Mina Harker. She was depicted as very beautiful, naturally voluptuous, sweet, innocent, and pure. In contrast to Mina's motherly characteristic, she was described in a more sexualized term and very adored by men. So much so that she received three marriage proposals from three different suitors on the same day. They were Quincey Morris, Dr. John Seward, and Arthur Holmwood, whom she chose to accept.

Much the same as Mina and the vampire brides, Lucy did not seem like she would fit the New Woman ideal. She was a delight and had muchpraised chastity and virtue, and she was the typical attractive young woman who was generally cherished by everyone. However, she also tends to show her hypersensitivity and sexual side. When the three men proposed to her, she expressed her surprise and desire to break gender norms and accept all three proposals, saying, "Why can't they let a girl marry three men, or as many as want her, and save all this trouble?" (Stoker, 1993, p. 51) Although she did not actually accept them all, she did kiss all three of them and had a rebellious thought that would break the traditional Victorian women's values and was seen as a moral weakness. Greg Buzwell from the British Library, in his article Dracula: Vampires, Perversity, and Victorian Anxieties, established in his article that through Lucy's moral weakness, such as her excessive emotions and sexual desire, she was disposed from the Victorian normativity and thus allowing Dracula to prey repeatedly upon her and 
"only a series of desperate blood transfusions from each of her former suitors - a sickly symbolic echo of Lucy's desire for three husbands (and thus three lovers) - delay, for a while, the inevitable." (Buzwell, 2014)

Another feature of Lucy that could be interpreted as a New Woman ideal is her intimate friendship with Mina. As referred by Prescott and Giorgio, this could be found in Lucy and Mina's level of self-conscious intimacy in their letters. "The only true intimate writing exchanged in the novel, these letters mark Lucy as an effusive, silly schoolgirl and sexually excessive New Woman." It was also pointed out that her most enthusiastic moments of pleasure and her most passionate connections are the ones that are directed towards her dearest friend Mina, not at any of her male suitors. In her letters to Mina, she used expressions such as "Oceans of love and millions of kisses" (Stoker, 1993, p. 89) and "I wish I were with you, dear, sitting by the fire undressing, as we used to sit, and I would try to tell you what I feel." (Stoker, 1993, p. 48), as well as her constant longing to be at her side as written in her diary, "I wish she were here with me again, for I feel so unhappy." (Stoker, 1993, p. 91) Through these words and declarations, she captured the intimacy of their gushing relationship. "Despite this homoerotic charge, Lucy and Mina remain unselfconscious about the nature of their friendship, valuing their intimacy not as sexual but as an idealized connection" (Prescott and Giorgio, 2005, p. 496).

In her vampire form, Lucy behaved in a manner that would have been seen as an affront to motherhood and femininity, as she was confronted by Van Helsing, "With a careless motion, she flung to the ground, callous as a devil, the child she had clutched strenuously to her breast, growling over it as a dog growls over a bone." (Stoker, 1993, p. 175) From that to her hyperfemininity and sensitivity as well as her excessive sensuality, Lucy's depiction of the New Woman ideal was rather subtle and not as straightforward as it could have been. As Buzwell claimed, her declined from the traditional Victorian women ideal to the "perceived selfish unnaturalness of the New Woman is complete" (Buzwell, 2014).

\section{CONCLUSION}

Using the objective approach and aligned with the aspect of the New Woman, this research has found characteristics of the women's roles in the novel that could be interpreted as going against the traditional values of Victorian women. Mina Harker, the lead female protagonist of the story, was introduced as the classic Victorian Britain woman, very motherly and gentle. Yet, she established the complexity of her characteristics as an independent and intelligent woman with her job as an assistant schoolmistress and her shorthand skills, and her ambition to do well and practice her skill in journalistic. Lucy Westenra, the more feminine and appealing character and the best friend of Mina, was portrayed as sexually excessive, a trait that is not common or acceptable in Victorian women, both before and after she turned into a vampire. The difference is that before, her sensuality was paired with her innocence and was seen as purity, whereas her vampirism increased her promiscuousness and was depicted as a threat to men. Lastly, the three brides of Count Dracula represent a contrast to Mina and Lucy, and they were the epitome of submissive and controlled individuals who were heavily dependent on their master.

Despite the contrast and complexity of their own dispositions, some of these characters' attributes go against the standards and ideals of Victorian women. And while the brides of Dracula conveyed the enslaved and oppressed women, Mina Harker and Lucy Westenra, in their subtler portrayal and not as straightforward as fighting for their rights to vote or as daring as protesting for equal wage, still conveyed the aspect of the New Woman ideal, regardless of its significance.

\section{REFERENCES}

Abrams, L. (2001). Ideals of womanhood in Victorian Britain. Retrieved from http://www.bbc.co.uk/history/trail/victorian_ britain/women_home/ideals_womanhood_01. shtml. 
Boyd, Kathryn. (2014). Making sense of Mina: Stoker's vampirization of the Victorian woman in Dracula. [Unpublished English honors thesis]. Trinity University, San Antonio, U.S.A. Retrieved from http://digitalcommons.trinity.edu/cgi/viewcon tent.cgi?article $=1019 \&$ context $=$ eng_honors .

Buzwell, G. (2014, May 15). Dracula: Vampires, Perversity and Victorian Anxieties. Retrieved from https://www.bl.uk/romantics-andvictorians/articles/dracula.

Cvetanova, L. (2014). Bram Stoker's "Dracula": Feminist theory and sexuality. GRIN Publishing.

Grand, S. (1894). The new aspect of the woman question. The North American Review, 158(448), 270-276.

Hughes, K. (2014, February 13). Gender roles in the 19th Century. Retrieved from http://www.bl.uk/romantics-andvictorians/articles/gender-roles-in-the-19thcentury.

Kent, S. K. (1990). Sex and suffrage in Britain 18601914. Routledge.
Mewald, K. (2008). The emancipation of Mina? The Portrayal of Mina in Stoker's Dracula and Coppola's Bram Stoker's Dracula. Journal of Dracula Studies, 10.

Pykett, L. (1992). The 'improper' feminine: The women's sensation novel and the new woman writing. Routledge.

Podonsky, A. M. (2010). Bram Stoker's Dracula: A reflection and rebuke of Victorian society. Inquiries Journal, 2(2), 1-2.

Prescott, C., \& Giorgio, G. (2005). Vampiric affinities: Mina Harker and the paradox of femininity in Bram Stoker's Dracula. Victorian Literature and Culture, 33(2), 487515.

Rosenberg, N. F. (2000) Desire and loathing in Bram Stoker's Dracula. Journal of Dracula Studies, 2.

Senf, C. A. (n.d). Rethinking the new woman in Stoker's fiction: Looking at Lady Athlyne. Journal of Dracula Studies, 9.

Stoker, B. (1993). Dracula. Penguin. 